\title{
DINÂMICA SEDIMENTAR DO FUNDO ESTUARINO ADJACENTE AO PORTO DE PARANAGUÁ
}

\author{
João Carlos Carrilho*
}

DISSERTAÇÃO DE MESTRADO - Programa de Pós-Graduação em Geologia - UFPR

DATA DE DEFESA: 25 fev. 2003

\begin{abstract}
O presente estudo, denominado Dinâmica sedimentar do fundo estuarino adjacente ao Porto de Paranaguá, tem como principal objetivo reconhecer aspectos da dinâmica dos sedimentos na baía de Paranaguá, estado do Paraná. A compreensão dos processos locais de erosão, transporte e deposição pode contribuir para o planejamento de obras portuárias e minimizar o impacto ambiental dessas intervenções. Um modelo detalhado da batimetria da área foi elaborado para descrever suas principais características e compará-las com levantamentos pretéritos, visando observar modificações num período de 39 anos. O mapeamento dos sedimentos da superfície de fundo, elaborado a partir de dados coletados em campanhas realizadas entre maio e novembro de 2001 , revelou que aproximadamente $70 \%$ da área é coberta por sedimentos finos $(<0,062 \mathrm{~mm})$, sendo que o restante possui
\end{abstract}

médias granulométricas entre areia fina e muito fina. Uma análise espacial foi elaborada em ambiente SIG, utilizando-se: 1) as informações das modificações históricas da batimetria; 2) o mapa de diâmetro médio dos sedimentos; 3 ) as velocidades críticas de correntes de maré (enchente e vazante) calculadas para o limiar de transporte dos sedimentos incoesivos; 4) as velocidades de cisalhamento medidas num ciclo de maré de sizígia no inverno de 2001. Como resultado dessa análise, foram identificados três locais com tendência à erosão e quatro locais com tendência ao assoreamento, próximos ao Porto de Paranaguá. O cálculo do balanço de circulação do material particulado em suspensão e a comparação batimétrica entre levantamentos recentes (pós e pré- dragagens) parecem confirmar os resultados da análise espacial na área frontal ao porto. 